March

March 21-26, 2010

15th Annual Update on Cardiopulmonary Bypass

Fairmont Chateau

Whister, BC, Canada

April

April 29-30, 2010

Aortic Symposium 2010

Sheraton New York Hotel and Towers

New York City, New York, USA

May

May 1-5, 2010

AATS 90th Annual Meeting

Metro Toronto Convention Centre

Toronto, Ontario, Canada

\section{AATS Academy Applications Now Available}

Thursday Evening and Friday, April 29 \& 30, 2010, Toronto, ON, Canada (Held immediately prior to the AATS Annual Meeting)

Applications are now available for the 2010 AATS Academy. The AATS Academy is an intensive didactic and interactive program for surgeons showing significant promise as potential future division chiefs or who have recently assumed the role of division chief. For additional information regarding the Academy please visit www.aats.org. Interested applicants should meet the following qualifications before applying:

- Achieved the rank of Associate Professor

- Active/successful clinical surgeon

- Evidence of local institutional and/or state/regional leadership ability

- Evidence of academic productivity including peer-reviewed publications and presentations at regional or national scientific meetings

- Funded research is preferable but not essential

Applications for consideration must be submitted electronically at www.aats.org by December 1, 2009. Academy participants will be selected by the Academy Committee and notified no later than February 5, 2010. The number of available slots is limited.

\section{Applications for Membership Now Available Online}

Applications for 2010 AATS Membership are now available with a deadline for submission of November 30, 2009. Applications received after the deadline will be automatically deferred until 2011. To apply for membership, a current member of the Association must act as the primary sponsor by initiating the application process in the Members Only area of the AATS Web site.

Although there are few hard and fast rules required for membership, the Association continues to look for surgeons from around the world with significant professional stature who possess exceptional clinical performance and have made significant contributions to the specialty with emphasis on the publication of scientific material in peerreviewed English-language journals. Interested applicants are encouraged to review the membership requirements and guidelines by visiting the AATS Web site at www. aats.org.

\section{Summer Intern Scholarship Applications Now Available}

The American Association for Thoracic Surgery (AATS) Summer Intern Scholarship program introduces the field of cardiothoracic surgery to first- and second-year medical students from North American medical institutions. By providing an opportunity to spend 8 weeks during the summer working in an AATS member's cardiothoracic surgery department, the summer intern scholarship provides medical students with insight into the scientific investigation and study of cardiothoracic surgery.

A grant of $\$ 4,000$ is provided to successful applicants to underwrite their living expenses during the 8 weeks of guidance at the selected host institution. Additionally, all awardees will receive complimentary registration to the Association's 2010 Annual Meeting and postgraduate courses taking place May 1-5 in Toronto, ON, Canada.

For more information and to submit an application, please visit the AATS Web site at www.aats.org. Application Deadline: January 15, 2010.

\section{The Western Thoracic Surgical Association}

\section{Applications for Membership}

Applications for membership in the Association must be received by the Membership Committee Chair no later than March 1, 2010 to be considered at the 2010 Annual Meeting. Applicants must be sponsored by three members of the Association who are not members of the Membership Committee. Application forms will be issued only to sponsoring members.

Address correspondence to:

Chair, Membership Committee 
The Western Thoracic Surgical Association 900 Cummings Center

Suite 221-U
Beverly, MA 01915

978-927-8330; fax: 978-524-8890

wtsa@prri.com

\section{The American Board of Thoracic Surgery}

\section{Notices}

The part I (written) examination was held on December 3. It is planned that this examination will be given at multiple sites throughout the United States using an electronic format. The closing date for registration is August 1 each year. Those wishing to be considered for examination must apply online at www.abts.org.

To be admissible for the Part II (oral) examination, a candidate must have successfully completed the Part I (written) examination.

A candidate applying for admission to the certifying examination must fulfill all the requirements of the Board in force at the time the application is received. Please address all communications to the American Board of Thoracic Surgery, 633 North St Clair Street, Suite 2320, Chicago, IL 60611 (telephone: 312-202-5900).

\section{Requirements for Maintenance of \\ Certification}

Diplomates of the American Board of Thoracic Surgery (ABTS) who plan to participate in the Maintenance of Certification (MOC) process must hold an unrestricted medical license in the locale of their practice and privileges in a hospital accredited by the JCAHO (or other organization recognized by the ABTS). In addition, a valid ABTS certificate is an absolute requirement for entrance into the Maintenance of Certification process. If your certificate has expired, the only pathway for renewal of a certificate is to take and pass the Part I (written) and the Part II (oral) certifying examinations.

The names of individuals who have not maintained their certificate will no longer be published in the American Board of Medical Specialties Directories. Diplomates' names will be published upon successful completion of the Maintenance of Certification process.
The CME requirements are 30 Category I credits earned during each year prior to application. At least half of these CME hours need to be in the broad area of thoracic surgery. Category II credits are not allowed. Interested individuals should refer to the Booklet of Information for Maintenance of Certification for a complete description of acceptable CME credits. Diplomates will be expected to submit verification of CME earned.

Diplomates in the Maintenance of Certification process will need to provide a summary of their major cases performed during the year prior to application. The practice review should not exceed 100 cases.

Diplomates in the Maintenance of Certification process will be required to complete all sections of the SESATS self-assessment examination. It is not necessary for Diplomates to purchase SESATS individually, because it will be sent to them after their application has been approved.

Diplomates may apply for Maintenance of Certification in the year their certificate expires, or if they wish to do so, they may apply up to two years before it expires. However, the new certificate will be dated 10 years from the date of expiration of their original certificate or most recent recertification certificate. In other words, going through the Maintenance of Certification process early does not alter the 10-year validation. Diplomates certified prior to 1976 (the year that time-limited certificates were initiated) are also required to participate in MOC if they wish to maintain valid certificates.

The deadline for submission of application for the Maintenance of Certification is May 10 of each year. All ABTS diplomates will receive a letter from the Board outlining their individual timeline and $\mathrm{MOC}$ requirements. A brochure outlining the rules and requirements for Maintenance of Certification in thoracic surgery is available upon request from the American Board of Thoracic Surgery, 633 North St. Clair Street, Suite 2320, Chicago, IL 60611; telephone (312) 202-5900; fax (312) 202-5960; email info@abts.org. This booklet is also published on the website: www.abts.org. 